\title{
Pemanfaatan Klasifikasi Soal Biologi Cognitive Domain Bloom's Taxonomy Menggunakan KNN Chi-Square Sebagai Penyusunan Naskah Soal
}

\author{
Indah Listiowarni $^{*}$, Nindian Puspa Dewi ${ }^{2}$ \\ ${ }^{1,2}$ Informatika, Fakultas Teknik, Universitas Madura \\ 1,2 Jln.Raya Panglegur KM 3,5 Pamekasan, Jawa Timur, Indonesia \\ e-mail: ${ }^{1}$ indah@unira.ac.id, ${ }^{2}$ nindianpd@unira.ac.id
}

\begin{abstract}
Abstrak
Naskah soal merupakan sebuah naskah yang berisi kumpulan soal-soal ujian yang biasa dipakai oleh seorang tenaga pendidik untuk menguji daya serap anak didiknya pada materi yang telah disampaikan di kelas.Naskah soal dibuat berdasarkan presentase tingkat kesulitan soal yang disesuaikan dengan kisi-kisi soal pada analisis intruksional, sehingga penelitian ini dilakukan Untuk membantu tenaga pendidik dalam menyusun naskah soal penelitian ini merupakan pengembangan dari penelitian yang telah dilakukan sebelumnya, yaitu dengan memanfaatkan hasil klasifikasi soal ujian mata pelajaran biologi menggunakan metode KNN dan chi-square yang menghasilkan performance tertinggi mencapai 79,36\% pada 4 kali percobaan dataset pertama dan 4 kali percobaan pada dataset kedua. Hasil klasifikasi tersebut akan digunakan sebagai penyusunan naskah soal sesuai dengan presentase dari setiap tingkat kesulitan soal ujian berdasarkan cognitive domain taxonomy blooms
\end{abstract}

Kata kunci: Taksonomi Bloom, KNN, chi-square, text mining, klasifikasi

\section{Abstract}

The question manuscript is a manuscript that contains a collection of exam questions that are usually used by an educator to test the absorption of their students on the material that has been presented in class. Manuscripts of questions are made based on the percentage of the difficulty level of the questions adjusted to the question grid in the instructional analysis, so this research was conducted to help educators in compiling the question manuscripts. This research is a development of research that has been done before, namely by utilizing the results of the classification of biology subject examination questions using the KNN and chi-square methods which resulted in the highest performance reaching $79.36 \%$ in the first 4 experiments on the first dataset and 4 experiments on the second dataset. . The classification results will be used as the preparation of the question text according to the percentage of each difficulty level of the exam questions based on the cognitive domain taxonomy blooms.

Keywords: bloom's taxonomy, KNN, chi-square, text mining, classification

\section{Pendahuluan}

Pembuatan naskah soal merupakan rangkaian yang harus dilakukan oleh seorang tenaga pendidik, ketika seorang guru akan melakukan pengayaan pada anak didiknya, baik berupa kuis, ulangan harian, hingga ujian akhir semester [1]. Naskah soal merupakan sebuah naskah yang berisi butiran-butiran soal yang disesuaikan dengan kecocokan materi dan jenis dari ujiannya. Naskah soal yang dibagikan kepada siswa saat ujian tidak asal dibuat, melainkan disesuaikan berdasarkan presentase soal ujian yang telah lebih dahulu dibuat [2], dimana pada kisi-kisi soal tersebut mengandung contoh soal dan jumlah presentase dari tingkat kesulitan soal berdasarkan cognitive domain taksonomi bloom.

Cognitive domain merupakan salah satu ranah dari tiga yang ada pada taksonomi bloom, cognitive domain digunakan untuk mengukur kemampuan kognitif siswa pada kegiatan belajarmengajar di lingkungan pendidikan [3]. Taksonomi bloom pertama kali digagas oleh ilmuwan 
bernama benjamin samuel bloom pada tahun 1956 dan disempurnakan oleh Lorin Anderson Krathwohl pada tahun 1994. Cognitive Domain Taxonomy Bloom terdiri dari 6 tingkatan yaitu pengetahuan (C1), pemahaman (C2), aplikasi (C3), analisis (C4), sintesis (C5) dan evaluasi (C6). Naskah soal yang baik harus memenuhi acuan dari yang telah disesuaiakan dengan jumlah perbandingan setiap class soal yang didalamnya terdapat formula jumlah presentase yang tepat dari setiap soal berlevel C1 sampai C6 [4]. Misalnya pada kuis mingguan yang bobotnya lebih ringan, dan hanya membutuhkan waktu yang relatif singkat dibandingkan dengan ulangan harian, maka soal berlevel $\mathrm{C} 1$ akan memiliki presentase yang lebih besar dibandingkan dengan soal berlevel lebih tinggi lainnya [5]

Tujan dari penelitian ini adalah menggunakan kombinasi metode classifier KNN dan metode feature selection chi-square untuk meng-klasifikasi-kan soal uraian biologi tingkat menjadi 6 class (C1-C6) sesuai dengan ranah kognitif taksonomi bloom [6], setelah data soal selesai diklasifikasi menjadi class-class yang sesuai, maka selanjutnya adalah menggunakan hasil klasifikasi tersebut untuk penysunan naskah soal, dimana naskah soal tersebut disusun berdasarkan jumlah presentase setiap class cognitive domain yang harus ada dalam setiap jenis naskah soal, misalkan jenis naskah soal $\mathrm{UH} / \mathrm{kuis}$ memiliki jumlah presentase class cognitive domain yang berbeda dengan jenis naskah soal UTS dan UAS[7] .

Penelitian mengenai klasifikasi jenis soal berdasarkan cognitive domain taksonomi bloom, pernah dilakukan yaitu dengan membandingkan metode KNN dengan 2 metode classifier lain nya yang dikombinasikan dengan 3 macam feature selection untuk mengategorikan data soal (examination) berdasarkan cognitive domain taksonomi bloom, dengan menggunakan Dataset yang merupakan soal ujian programming dari jurusan Teknologi Informasi pada tahun pertama hingga tahun ketiga di Fakultas Information Science dan Technology UKM, pada penelitian tersebut classifier KNN unggul dibandingkan dua classifier lainnya, yaitu mencapai performance 89,8\% (2015)[8]. Pengkategorian soal juga pernah dilakukan oleh Selvia dkk menggunakan task-task NLP, dengan bantuan metode SVM, data yang digunakan merupakan butir-butir soal mata pelajaran Bahasa Indonesia, Matematika, IPA, IPS dan PPKN (2015)[9]. Penerapan dan perbandingan metode KNN dan KNN+Gini Index dilakukan pada dataset soal-soal berbahasa inggris, dan mendapatkan KNN dengan pengurangan fitur dengan menggunakan fitur selection atau Gini index mendapatkan hasil lebih baik dibandingkan KNN biasa [10]

Pengkategorian soal dengan menggunakan metode yang sama dan dataset yang serupa pernah dipublikasikan sebelumnya, untuk mengetahui akurasi dan hasil performance dari metode usulan, dalam penelitian sebelumnya, didapatkan akurasi mencapai 79,36\% pada dataset pertama, dan mendapatkan nilai F-measure mencapai 61,56\% untuk dataset jenis kedua [6], pada penelitian ini dilakukan sebuah pengembangan berupa pemanfaatan hasil klasifikasi butir soal biologi untuk digunakan sebagai penyusunan naskah soal yang terdiri dari kuis/UH, UTS, dan UAS. Pembaruan dalam penelitian ini merupakan sebuah system yang dapat melakukan penyusunan naskah soal sesuai hasil klasifikasi taksonomi bloom dan secara otomatis menyesuaikan jumlah presentase dari setiap jumlah class yang telah ditetapkan.

\section{Metode Penelitian}

Sebuah metode penelitian merupakan sebuah cara dan langkah yang dipilih oleh peneliti untuk membangun sebuah system atau melakukan sebuah penelitian untuk mendapatkan hasil yang diinginkan dari sebuah penelitian yang dilakukan. Tahapan/metode pembangunan system yang digunakan sebagai acuan di dalam penelitian ini adalah metode waterfall, yaitu sebuah metode penelitian yang dilakukan secara sekuensial atau berurutan[11], dimana dalam penelitian ini akan dilakukan beberapa rangkaian penelitian yang dapat dilihat pada gambar 1 .

Penelitian ini merupakan sebuah penelitian lanjutan dari penelitian yang sudah dilakukan tentang proses klasifikasi soal ujian mata pelajaran biologi SMA untuk mengetahui class-nya berdasarkan dengan ranah cognitive taksonomi bloom yang terdiri dari 6 class (pengetahuan (C1), pemahaman (C2), aplikasi (C3), analisis (C4), sintesis (C5) dan evaluasi (C6)), serta menggunakan metode KNN dan feature selection chi-square [6], sedangkan pada penelitian ini 
adalah memanfaatkan hasil klasifikasi pada penelitian sebelumnya untuk digunakan sebagai bahan penyusunan naskah ujian.

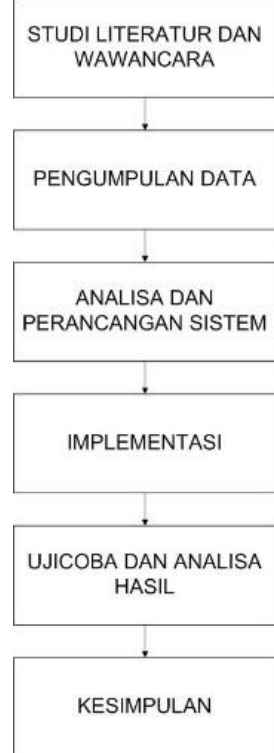

Gambar 1. Flow Aktivitas Penelitian

Seperti yang telah dijelaskan pada gambar 1, tahapan waterfall yang akan digunakan pada penelitian ini terdiri dari 6 langkah penelitian yaitu studi literatur dan wawancara, pengumpulan data, Analisa dan perancangan system, impelementasi, ujicoba dan Analisa hasil, serta diakhiri dengan kesimpulan. Seperti yang telah disebutkan sebelumnya, metode pembangunan waterfall dikerjakan secara berurutan atau sekuensial, sehingga jika tahapan diatasnya belum dilaksanakan, maka tahapan berikutnya tidak dapat berjalan dengan baik [12]

Pada tahapan pertama aktivitas penelitian dilakukan studi literatur dan pendalaman teori, yaitu membaca, memahami dan mendalami beberapa studi literatur mengenai Pustaka-pustaka yang mendukung dalam proses penelitian dan pengembangan (pembangunan) system, yaitu :

(a) Taksonomi Bloom dan keywords yang mendukung dalam 6 tingkatan cognitive domain taksonomi bloom yang dijadikan sebagai acuan klasifikasi

(b) Metode/langkah yang digunakan sebagai acuan pengerjaan dalam pembangunan system, yaitu metode waterfall

(c) Metode dan pendukung metode yang digunakan untuk meng-klasifikasi soal ujian, yaitu metode K-Nearest Neighbour dan chi-square

Selain melakukan studi literatur, pada tahapan ini peneliti juga melakukan wawancara dengan beberapa pihak yang dianggap sebagai pakar yang mengerti tentang taksonomi bloom dan tingkatannya, serta dapat mengenali soal-soal ujian ke dalam salah satu tingkatan ranah kognitif taksonomi bloom, beberapa pihak yang dimaksud adalah Wakil Kepala Sekolah (WAKA) Kurikulum SMAN 5 Pamekasan, Wakil Kepala Sekolah (WAKA) Kesiswaan SMAN 5 Pamekasan, Guru/tenaga Pendidik bidang biologi, serta berbagai pihak yang dianggap mengetahui perihal soal biologi dan klasifikasi nya dalam taksonomi bloom ranah kognitif..

\subsection{Dataset}

Data yang digunakan dalam penelitian ini didapatkan dari beberapa sumber, yaitu : Internet, Buku Mata Pelajaran Biologi, Lembar Kerja Siswa Biologi, dan Soal-soal UTS/UAS/Kuis/UN biologi.Sehingga, dalam penelitian ini akan digunakan 600 data soal uraian biologi, atau yang terdiri dari 7824 term.

Soal-soal biologi tersebut akan dibagi menjadi 6 tingkatan class cognitive domain bloom's taxonomy. Taksonomi bloom merupakan sebuah tingkatan level taksonomi yang biasa dipakai dalam ranah Pendidikan. Lorin Anderson Krathwohl merupakan seorang ahli yang 
menyempurnakan taksonomi bloom pada tahun 1994, setelah sebelumnya digagas oleh pada tahun 1956 oleh ahli bernama Benjamin Samuel Bloom. Hingga saat ini taksonomi bloom digunakan untuk memberikan level pada 3 ranah di bidang Pendidikan yaitu ranah psikomotorik (P), Afektif (A) dan Kognitif (K) [13]. Tingkatan soal sesuai ranah kognitif sebagai acuan ditunjukkan pada gambar 2 tentang piramida taksonomi.

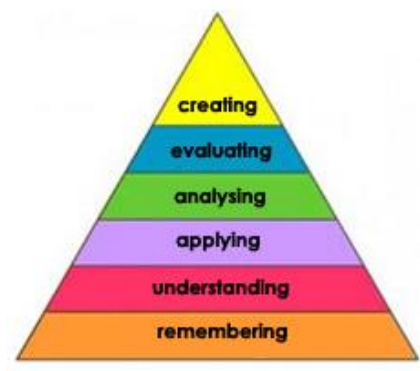

Gambar 2. Kognitif taksonomi bloom [14]

Piramida pada gambar 2 menjelaskan tentang tingkatan level pada kognitif domain taksonomi bloom, creating atau membuat merupakan tingkatan/level tertinggi pada kognitif domain, yang selanjutnya dalam penelitian ini akan disebut sebagai C6, sedangkan remembering atau mengingat merupakan tingkatan terendah dari kognitif domain taksonomi bloom, yang selanjutnya dalam penelitian ini akan disebut sebagai $\mathrm{C} 1$.

\subsection{System Usability Scale}

SUS atau System Usability Scale pertama kali dibuat oleh John Brooke pada tahun 1986 [15] dan digunakan untuk melakukan ujicoba kegunaan sebuah system dengan cara mengajukan beberapa pertanyaan tertentu ke sekolompok partisipan [16]. SUS memiliki 10 pertanyaan dengan 5 pilihan jawaban yang berupa deretan angka 1-5 yang mencerminkan jawaban partisipan dari sangat setuju sampai sangat tidak setuju. Tabel 1 merupakan 10 pertanyaan yang akan digunakan sebajai uji usability pada penelitian ini

Tabel 1 Komponen pertanyaan SUS [17]

\begin{tabular}{lll}
\hline $\mathbf{N o}$ & Pernyataan & Skala \\
\hline $\mathbf{1}$ & $\begin{array}{l}\text { I think that I would like to use this system frequently (Saya pikir bahwa saya akan } \\
\text { ingn lebih sering menggunakan aplikasi ini) }\end{array}$ & $1 \mathrm{~s} / \mathrm{d} 5$ \\
\hline $\mathbf{2}$ & $\begin{array}{l}\text { Ifound the system unnecessarily complex. (Saya meemukan bahwa aplikasi ini, tidak } \\
\text { harus dibuat serumit ini) }\end{array}$ & $1 \mathrm{~s} / \mathrm{d} 5$ \\
\hline $\mathbf{3}$ & I thought the system was easy to use (Saya pikir aplikasi mudah untuk digunakan) & $1 \mathrm{~s} / \mathrm{d} 5$ \\
\hline $\mathbf{4}$ & $\begin{array}{l}\text { I think that I would need the support of a technical person to be able to use this } \\
\text { system. (Saya pikir bahwa saya akan membutuhkan bantuan dari orang teknis untuk } \\
\text { dapat menggunakan aplikasi ini) }\end{array}$ & $1 \mathrm{~s} / \mathrm{d} 5$ \\
$\mathbf{5}$ & $\begin{array}{l}\text { Ifound the various functions in this system were well integrated (Saya meneukan } \\
\text { berbagai fungsi di aplikasi ini diintegrasikan dengan baik) }\end{array}$ & $1 \mathrm{~s} / \mathrm{d} 5$ \\
\hline $\mathbf{6}$ & $\begin{array}{l}\text { I thought there was too much inconsistency in this system (Saya pikir ada terlalu } \\
\text { banyak ketidaksesuaian dalam aplikasi ini) }\end{array}$ & $1 \mathrm{~s} / \mathrm{d} 5$ \\
\hline $\mathbf{7}$ & $\begin{array}{l}\text { I would imagine that most people would learn to use this system very quickly (Saya } \\
\text { bayangkan bahwa kebanyakan orang akan mudah untuk mempelajari aplikasi ini } \\
\text { dengan sangat cepat) }\end{array}$ & $1 \mathrm{~s} / \mathrm{d} 5$ \\
\hline $\mathbf{8}$ & $\begin{array}{l}\text { Ifound the system very cumbersome to use (Saya menemukan, aplikasi ini sangat } \\
\text { rumit untuk digunakan) }\end{array}$ & $1 \mathrm{~s} / \mathrm{d} 5$ \\
\hline $\mathbf{9}$ & $\begin{array}{l}\text { Ifelt very confident using the system (Saya merasa sangat percaya diri untuk } \\
\text { menggunakan aplikasi ini) }\end{array}$ & $1 \mathrm{~s} / \mathrm{d} 5$ \\
\hline $\mathbf{1 0}$ & $\begin{array}{l}\text { I needed to learn a lot of things before I could get going with this system (Saya perlu } \\
\text { belajar banyak hal sebelum saya bisa memulai menggunakan aplikasi) }\end{array}$ & $1 \mathrm{~s} / \mathrm{d} 5$ \\
\hline
\end{tabular}

Berikut aturan perhitungan SUS [18] :

1. Pertanyaan dengan nomor ganjil, skor pertanyaan dari skor pengguna dikurangi $1(\mathrm{X}-1)$. 
2. Pertanyaan dengan nomor genap, skor akhir didapat dari nilai 5 dikurangi skor pertanyaan yang didapat dari pengguna (5-X).

3. Skor akhir SUS didapat dari hasil penjumlahan seluruh skor dari setiap pertanyaan yang kemudian dikali 2,5.

\subsection{K-Nearest Neighbour}

KNN atau kependekan dari K-Nearest Neighbour merupakan salah satu metode klasifikasi yang memiliki performance yang baik [19]. Metode KNN termasuk ke dalam jenis supervised learning, dimana dalam prosesnya, metode ini membutuhkan data training untuk belajar. Semakin besar data training yang digunakan dalam proses learning khususnya untuk metode supervised learning, maka semakin baik performance yang dihasilkan [20]. Pada dasarnya, KNN (K-Nearest Neighbour) mencari similarity (tingkat kemiripan) data dengan menggunakan pengukuran distance (jarak). Pada penelitian ini digunakan Euclidean distance untuk menghitung similarity dari dua data atau lebih.

$$
\begin{aligned}
& \mathrm{d}_{\left(\mathrm{x}_{1}, \mathrm{x}_{2}\right)}=\sqrt{\left(\left|\mathrm{x}_{11}-\mathrm{x}_{21}\right|\right)^{2}+\left(\left|\mathrm{x}_{12}-\mathrm{x}_{22}\right|\right)^{2}} \\
& \text { Dimana } \\
& \mathrm{d} \quad \text { : distance } \\
& \mathrm{x} 1 \quad \text { : data 1 } \\
& \mathrm{x} 2 \quad \text { : data 2 }
\end{aligned}
$$

\subsection{Chi-Square}

Chi-Square merupakan salah satu metode feature selection yang termasuk metode filter [21]. Dikatakan sebagai metode filter karena chi-square disini digunakan untuk mengeliminasi term yang tidak memenuhi threshold, sehingga lebih berefek pada cost., dan akurasi dari sebuah metode. Metode feature selection terbukti dapat meningkatkan akurasi pada beberapa penelitian sebelumnya[8][22]. Berikut adalah formula yang digunakan untuk menerapkan metode feature selection chi-square .

$X^{2}(t, c)=\frac{N(A \times D-B \times C)^{2}}{(A+B) \times(C+D) \times(A+C) \times(B+D)}$

Dimana :

$\mathrm{t}:$ term

$\mathrm{n}:$ jumlah dokumen

A : jumlah dokumen pada kelas $c$ yang mengandung term $t$

$\mathrm{B}$ : jumlah dokumen yang tidak ditemukan pada class $c$ tapi mengandung term $t$

C : jumlah dokumen yang ditemukan di class $c$ namun tidak mengandung term $t$

D : jumlah dokumen yang bukan merupakan dokumen kelas $c$ dan tidak mengandung term $t$

\subsection{Ujicoba dan Analisa Hasil}

Tahapan ujicoba merupakan tahapan ketika tahapan implementasi selesai dilakukan, pada tahapan ini dilakukan uji coba dengan menggunakan kombinasi jumlah perbandingan data training dan data testing hingga didapatkan akurasi terbaik. Dataset yang digunakan pada penelitian ini berjumlah 600 data dengan total 7824 term di dalamnya. Kemudian, setelah hasil klasifikasi didapatkan dengan akurasi yang diinginkan, maka ujicoba selanjutnya adalah penyusunan naskah soal sesuai dengan tipe ujian dan jumlah presentase yang telah ditetapkan pada kisi-kisi soal, dengan menggunakan pengujian usability menggunakan SUS (System Usability Scale)

\section{Hasil dan Pembahasan}

Tujuan penelitian ini, adalah menggunakan hasil klasifikasi soal ujian biologi berdasarkan ranah kognitif taksonomi bloom yang sudah diklasifikasikan menjadi 6 class yaitu yaitu yaitu pengetahuan (C1), pemahaman (C2), aplikasi (C3), analisis (C4), sintesis (C5) dan evaluasi (C6) hasil kasifikasi soal tersebut akan digunakan sebagai bahan naskah biologi, dimana presentase 
nya sudah ditentukan sebelumnya. Berikut adalah jumlah presentase setiap class soal biologi dalam setiap tipe naskah soal ujian yang dijelaskan pada tabel 2 .

Tabel 2.Presentase jumlah class biologi dan jenis naskah

\begin{tabular}{lcccccc}
\hline \multirow{2}{*}{ Jenis } & \multicolumn{7}{c}{$\boldsymbol{C 1}$} & $\boldsymbol{C 2}$ & $\boldsymbol{C 3}$ & & $\boldsymbol{C 4}$ & $\boldsymbol{C 5}$ & $\boldsymbol{C 6}$ \\
\cline { 2 - 7 } & 40 & 20 & 10 & 10 & 10 & 10 \\
Kuis/UH & 10 & 15 & 15 & 20 & 20 & 20 \\
UTS & 10 & 15 & 15 & 20 & 20 & 20
\end{tabular}

Sesuai dengan rancangan penelitian yang ditunjukkan pada gambar 3 , penelitian ini terdiri dari dua proses besar, yaitu proses klasifikasi soal biologi menjadi 6 class berdasarkan kognitif domain taksonomi bloom, dan dilanjutkan dengan proses pembagian hasil klasifikasi soal ke dalam naskah soal sesuai dengan jumlah presentase jumlah class soal yang diinginkan seperti yang tercantum pada tabel 2 .

\subsection{Klasifikasi Soal}

Proses klasifikasi soal uraian biologi yang disesuiakan dengan class ranah biologi taksonomi bloom didahului oleh pre-processing, tahapan pre-processing dalam proses ini terdiri dari labelling, tokenizing, casefolding, stopword, dan stemming kemudian dilanjutkan feature selection, yang dalam penelitian ini menggunakan feature selection chi-square, untuk tahapan pre-processing dalam proses ini digambarkan dalam gambar 4, dimana tahapan pre-processing tersebut dilakukan secara beruntun, yaitu output dari tahapan sebelumnya merupakan input untuk tahapan selanjutnya, dan seterusnya. Misalkan soal biologi yang telah selesai di tokenizing (pemotongan) akan dilanjutkan dengan casefolding, dan term yang sudah terpotong dan mengalami penyeragaman ukuran huruf akan dilakukan pengecekan stop-word pada proses stop word removal, stop word yang digunakan sebagai filter pada proses stop word removal berjumlah 1093 kata.

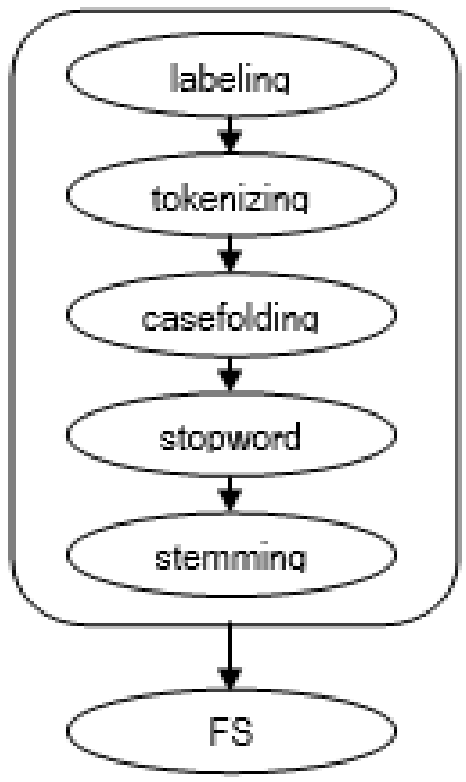

Gambar 4. Pre-processing

Tahapan pre-processing dilakukan secara otomatis oleh system, Tabel 3 menunjukkan hasil pre-processing yang dilakukan oleh system 
Tabel 3. Hasil Pre-processing

\begin{tabular}{|c|c|c|c|c|c|c|}
\hline No & data soal & token & case & stop & stem & class \\
\hline 1 & $\begin{array}{l}\text { Tuliskan jenis- } \\
\text { jenis sel T dan } \\
\text { peranan nya } \\
\text { dalam respon } \\
\text { imunitas }\end{array}$ & $\begin{array}{l}\text { Tuliskan jenis } \\
\text { jenis sel T dan } \\
\text { peranan nya } \\
\text { dalam respon } \\
\text { imunitas }\end{array}$ & $\begin{array}{l}\text { tuliskan jenis } \\
\text { jenis sel } t \text { dan } \\
\text { peranan nya } \\
\text { dalam respon } \\
\text { imunitas }\end{array}$ & $\begin{array}{l}\text { tuliskan sel } \\
\text { peranan respon } \\
\text { imunitas }\end{array}$ & $\begin{array}{l}\text { tulis sel peran } \\
\text { respon imunitas }\end{array}$ & $\mathrm{C} 1$ \\
\hline 2 & $\begin{array}{l}\text { Faktor-faktor } \\
\text { apakah yang } \\
\text { dapat } \\
\text { menurunkan } \\
\text { kekebalan } \\
\text { tubuh }\end{array}$ & $\begin{array}{l}\text { Faktor faktor } \\
\text { apakah yang } \\
\text { dapat } \\
\text { menurunkan } \\
\text { kekebalan } \\
\text { tubuh }\end{array}$ & $\begin{array}{l}\text { faktor faktor } \\
\text { apakah yang } \\
\text { dapat } \\
\text { menurunkan } \\
\text { kekebalan tubuh }\end{array}$ & $\begin{array}{l}\text { faktor faktor } \\
\text { menurunkan } \\
\text { kekebalan } \\
\text { tubuh }\end{array}$ & $\begin{array}{l}\text { faktor faktor } \\
\text { turun kebal } \\
\text { tubuh }\end{array}$ & $\mathrm{C} 1$ \\
\hline 3 & $\begin{array}{l}\text { Apa yang } \\
\text { dimaksud } \\
\text { dengan } \\
\text { gangguan } \\
\text { pernapasan } \\
\text { asfiksia }\end{array}$ & $\begin{array}{l}\text { Apa yang } \\
\text { dimaksud } \\
\text { dengan } \\
\text { gangguan } \\
\text { pernapasan } \\
\text { asfiksia }\end{array}$ & $\begin{array}{l}\text { apa yang } \\
\text { dimaksud } \\
\text { dengan } \\
\text { gangguan } \\
\text { pernapasan } \\
\text { asfiksia }\end{array}$ & $\begin{array}{l}\text { dimaksud } \\
\text { gangguan } \\
\text { pernapasan } \\
\text { asfiksia }\end{array}$ & $\begin{array}{l}\text { maksud ganggu } \\
\text { napas asfiksia }\end{array}$ & $\mathrm{C} 1$ \\
\hline 4 & $\begin{array}{l}\text { Apa yang } \\
\text { dimaksud } \\
\text { cangkok kulit }\end{array}$ & $\begin{array}{l}\text { Apa yang } \\
\text { dimaksud } \\
\text { cangkok kulit }\end{array}$ & $\begin{array}{l}\text { apa yang } \\
\text { dimaksud } \\
\text { cangkok kulit }\end{array}$ & $\begin{array}{l}\text { dimaksud } \\
\text { cangkok kulit }\end{array}$ & $\begin{array}{l}\text { maksud } \\
\text { cangkok kulit }\end{array}$ & $\mathrm{C} 1$ \\
\hline 5 & $\begin{array}{l}\text { Sebutkan bahan } \\
\text { makanan yang } \\
\text { banyak } \\
\text { mengandung } \\
\text { asam lemak } \\
\text { omega } 3\end{array}$ & $\begin{array}{l}\text { Sebutkan bahan } \\
\text { makanan yang } \\
\text { banyak } \\
\text { mengandung } \\
\text { asam lemak } \\
\text { omega }\end{array}$ & $\begin{array}{l}\text { sebutkan bahan } \\
\text { makanan yang } \\
\text { banyak } \\
\text { mengandung } \\
\text { asam lemak } \\
\text { omega }\end{array}$ & $\begin{array}{l}\text { sebutkan bahan } \\
\text { makanan asam } \\
\text { lemak omega }\end{array}$ & $\begin{array}{l}\text { sebut bahan } \\
\text { makan asam } \\
\text { lemak omega }\end{array}$ & $\mathrm{C} 1$ \\
\hline 6 & $\begin{array}{l}\text { Sebutkan } 6 \text { ciri } \\
\text { pembuluh vena } \\
\text { dan arteri }\end{array}$ & $\begin{array}{l}\text { Sebutkan ciri } \\
\text { pembuluh vena } \\
\text { dan arteri }\end{array}$ & $\begin{array}{l}\text { sebutkan ciri } \\
\text { pembuluh vena } \\
\text { dan arteri }\end{array}$ & $\begin{array}{l}\text { sebutkan ciri } \\
\text { pembuluh vena } \\
\text { arteri }\end{array}$ & $\begin{array}{l}\text { sebut ciri buluh } \\
\text { vena arteri }\end{array}$ & C1 \\
\hline 7 & $\begin{array}{l}\text { Sebutkan } 6 \\
\text { faktor yang } \\
\text { diduga dapat } \\
\text { meningkatkan } \\
\text { resiko } \\
\text { terjadinya } \\
\text { banjir } \\
\end{array}$ & $\begin{array}{l}\text { Sebutkan faktor } \\
\text { yang diduga } \\
\text { dapat } \\
\text { meningkatkan } \\
\text { resiko } \\
\text { terjadinya } \\
\text { banjir }\end{array}$ & $\begin{array}{l}\text { sebutkan faktor } \\
\text { yang diduga } \\
\text { dapat } \\
\text { meningkatkan } \\
\text { resiko } \\
\text { terjadinya banjir }\end{array}$ & $\begin{array}{l}\text { sebutkan faktor } \\
\text { diduga } \\
\text { meningkatkan } \\
\text { resiko } \\
\text { terjadinya } \\
\text { banjir }\end{array}$ & $\begin{array}{l}\text { sebut faktor } \\
\text { duga tingkat } \\
\text { resiko jadi } \\
\text { banjir }\end{array}$ & $\mathrm{C} 1$ \\
\hline 8 & $\begin{array}{l}\text { Tuliskan contoh } \\
\text { peristiwa difusi } \\
\text { dan osmosis }\end{array}$ & $\begin{array}{l}\text { Tuliskan contoh } \\
\text { peristiwa difusi } \\
\text { dan osmosis }\end{array}$ & $\begin{array}{l}\text { tuliskan contoh } \\
\text { peristiwa difusi } \\
\text { dan osmosis }\end{array}$ & $\begin{array}{l}\text { tuliskan } \\
\text { peristiwa difusi } \\
\text { osmosis }\end{array}$ & $\begin{array}{l}\text { tulis peristiwa } \\
\text { difusi osmosis }\end{array}$ & $\mathrm{C} 1$ \\
\hline
\end{tabular}

pada Tabel 3, proses pre-processing pada sistem berakhir pada tahapan stemming, selanjutnya data soal yang telah selesai di-steming akan dikenai proses perhitungan feature selection chi-square dengan menggunakan persamaan (2), tampilan proses feature selection chisquare mulai dari menghasilkan nilai A, B, C, dan D hingga mendapatkan nilai chi-square pada masing-masing class perolehan dari sistem ditunjukkan pada gambar 6

Pada gambar 6 menampilkan tampilan perhitungan chi-square pada system, dengan menggunakan tabel kontingensi pada tabel 1 digunakan untuk mendapatkan nilai A, B, C, dan D, kemudian untuk mendapatkan nilai chi untuk setiap class menggunakan persamaan (2), kemudian nilai chi yang memenuhi ambang batas yaitu 0,5 dari setiap class, yang akan menentukan term yang dimaksud akan di-eliminasi atau dibiarkan. 


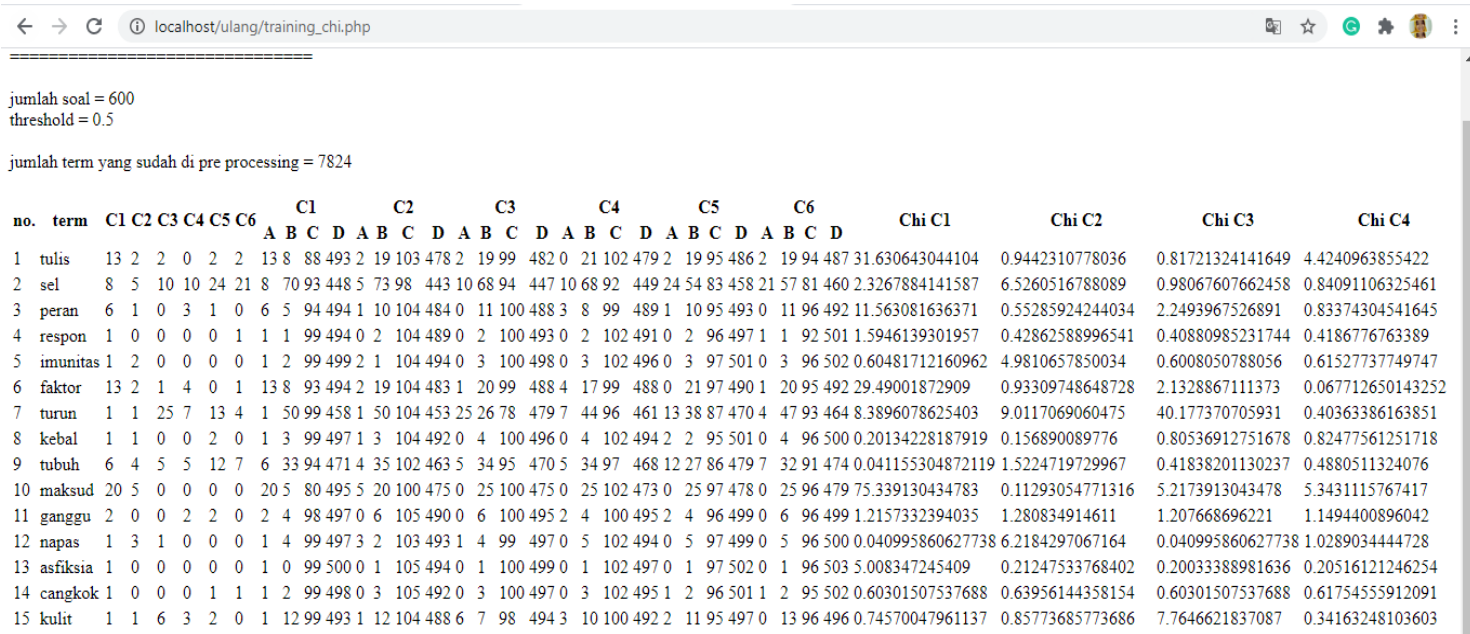

Gambar 6. Chi-square

Setelah melewati rangkaian pre-processing dan perhitungan eliminasi term yang tidak diperlukan menggunaan feature selection chi-square, kemudaian data soal biologi akan diklasifikasikan menggunakan metode KNN. Perfomance dari metode K-nearest neighbour (KNN) bergantung pada pemilihan $\mathrm{K}$ nya, pada penelitian sebelumnya, nilai perfomance tertinggi didapatkan ketika nilai $\mathrm{K}=5$ [6]

Sehingga pada penelitian nilai $\mathrm{K}$ yang digunakan adalah 5 , dengan menggunakan data training 600 data soal biologi dengan jumlah total 7824 term, didapatkan nilai perfomance pada beberapa percobaan pada sejumlah data soal yang merupakan bagian dari data training. Tabel 4 menunjukkan hasil pengujian.

Terkait dengan jumlah data training yang digunakan, jumlahnya dapat berubah sesuai dengan keinginan user seiring dengan berjalannya waktu untuk memperkaya data training dan jumlah term pada labeled class, karena semakin kaya term atau semakin banyak data training yang digunakan dalam sebuah proses klasifikasi akan memberi pengaruh positif pada akurasi yang dihasilkan[23]. Pengguna dapat menambahkan labeled question sebagai data training pada system dengan menggunakan fitur tambah yang terdiri dari tambah manual satu per-satu data soal uraian biologi atau secara bersamaan dengan menggunakan form excel.

Tabel 4. Perfomance pengujian

\begin{tabular}{ll}
\hline \multicolumn{1}{c}{ Jumlah data testing } & \multicolumn{1}{c}{ KNN-chi } \\
\hline $\mathbf{1 0}$ & 42,34 \\
\hline $\mathbf{2 5}$ & 79,36 \\
\hline $\mathbf{5 0}$ & 74,41 \\
\hline $\mathbf{1 0 0}$ & 76,71 \\
\hline
\end{tabular}

Gambar 8 merupakan salah satu cara yang dapat digunakan oleh pengguna untuk menambahkan labeled question ke dalam daftar data training.

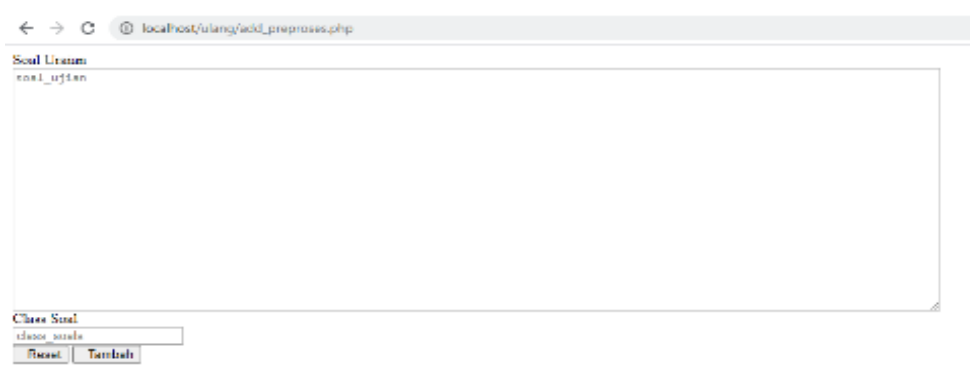

Gambar 8. Tambah labeled question 


\subsection{Naskah Soal}

Setelah tahap klasifikasi selesai dilakukan, dan berhasil mengklasifikasikan soal uraian biologi ke masing-masing class ranah kognitif taksonomi bloom, sesuai dengan perancangan system yang telah dirancang sebelumnya pada gambar 3, langkah selanjutnya adalah menggunakan hasil klasifikasi soal uraian biologi untuk disusun menjadi bagian dari naskah soal sesuai dengan jumlah presentase soal yang telah ditentukan sebelumnya pada tabel 3 .

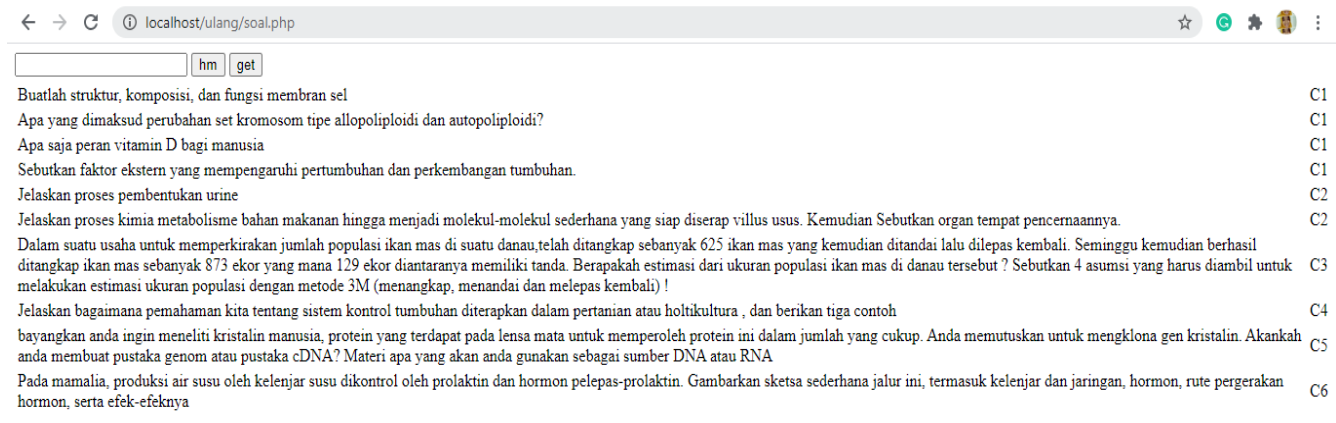

Gambar 9. Hasil naskah soal berjenis kuis

Gambar 9 merupakan tampilan hasil generate naskah kisi-kisi soal, berjenis kuis dengan jumlah 10 soal. Cara yang sama juga dilakukan untuk melakukan melakukan generate naskah kisi-kisi soal berjenis UTS dan UAS, yang dapat digunakan sebagai latihan siswa di dalam kelas, atau bisa digunakan oleh referensi oleh guru untuk menyusun naskah soal sebenarnya..

Pengujian usability dilakukan dengan menggunakan kuisioner SUS terhadap 10 responden, yaitu 2 guru mata pelajaran biologi SMAN 5 Pamekasan, dan 8 lainnya merupakan guru mata pelajaran biologi dari sekolah lain yang tergabung dalam MGMP (Musyawarah Guru Mata Pelajaran). Tabel 5 menunjukkan hasil perhitungan SUS dari 10 partisipan yang mengisi kuisioner.

Tabel 5. Hasil Perhitungan SUS

\begin{tabular}{llllllllllll}
\hline Participant & $\mathbf{q 1}$ & $\mathbf{q 2}$ & $\mathbf{q 3}$ & $\mathbf{q 4}$ & $\mathbf{q 5}$ & $\mathbf{q 6}$ & $\mathbf{q 7}$ & $\mathbf{q 8}$ & $\mathbf{q 9}$ & $\mathbf{q 1 0}$ & $\begin{array}{l}\text { Skor } \\
\text { SUS }\end{array}$ \\
\hline p1 & & & & & & & & & & & \\
\hline p2 & 5 & 3 & 5 & 4 & 5 & 3 & 3 & 2 & 1 & 42,5 \\
\hline p3 & 5 & 2 & 5 & 2 & 4 & 2 & 4 & 2 & 4 & 1 & 82,5 \\
\hline p4 & 3 & 3 & 3 & 1 & 3 & 3 & 3 & 3 & 3 & 3 & 55,0 \\
\hline p5 & 4 & 2 & 4 & 2 & 4 & 2 & 4 & 2 & 4 & 2 & 75,0 \\
\hline p6 & 5 & 2 & 5 & 2 & 4 & 2 & 4 & 2 & 4 & 1 & 82,5 \\
\hline p7 & 3 & 2 & 4 & 2 & 4 & 2 & 4 & 2 & 4 & 2 & 72,5 \\
\hline p8 & 5 & 1 & 5 & 1 & 3 & 1 & 4 & 2 & 4 & 1 & 87,5 \\
\hline p9 & 4 & 2 & 3 & 2 & 4 & 2 & 4 & 2 & 4 & 2 & 72,5 \\
\hline p10 & 5 & 2 & 3 & 1 & 4 & 2 & 4 & 2 & 4 & 1 & 80,0 \\
\hline Rata-rata & 5 & 2 & 5 & 2 & 4 & 3 & 4 & 2 & 4 & 1 & 80,0 \\
\hline
\end{tabular}

Berdasarkan nilai rata-rata SUS yang didapatkan, maka diperoleh nilai 73,0 berdasarkan rentan nilai SUS nilai tersebut dapat digolongkan menjadi "good"/"layak" [24]. Sedangkan hasil klasifikasi yang didapatkan dengan menggunakan metode usulan (KNN + Chi Square) penelitian ini masih mendapatkan nilai performance dibawah penelitian terdahulu dengan 
menggunakan metode yang sama dengan selisih 10,2\% [8]. Tetapi masih sama baiknya dengan penelitian sebelumnya yang menggunakan task-task NLP dan metode klasifikasi SVM sebagai classifier, yaitu performance terendah nya 66,0\% pada kernel RBF dan mencapai 73,2\% untuk polynomial orde 2 , dan $75,4 \%$ untuk polynomial orde ke 3 [9]. Penelitian ini memiliki performance lebih baik dengan selisih $10,99 \%$ untuk performance terbaiknya menggunakan $\mathrm{KNN}+$ Gini [10]

\section{Kesimpulan}

Metode KNN dan Chi-Square berhasil mengklasifikasikan soal ujian biologi ke dalam class pada cognitive domain taksonomi bloom, dengan nilai tertinggi akutasi mencapai 79,36 dengan menggunakan 25 data testing terhadap 600 data training dengan jumlah total term 7824 term. Hasil klasifikasi KNN dan Chi-Square berupa soal biologi yang berhasil di klasifiasi menjadi kumpulan soal yang memiliki class (c1-c6) dapat digunakan untuk penyusunan soal kuis/UH, UTS dan UAS sesuai persentase yang diinginkan, dan mendapatkan skor SUS 73,0 dengan grade yang dapat digolongkan "good"/"layak"/"B" untuk pengujian usability .

\section{Ucapan Terimakasih}

Terima kasih kepada Direktorat Riset dan Pengabdian kepada Masyarakat khususnya Direktorat Jenderal Penguatan Riset dan Pengembangan atas bantuan dana penelitian yang telah diberikan, sehingga penelitian ini dapat dilakukan, dilaksanakan dan diterapkan dengan baik. Terima kasih juga penulis ucapkan untuk semua pihak yang membantu dalam pelaksanaan dan keberlangsungan penelitian ini.

\section{Daftar Pustaka}

[1] Rozi, "upaya kepala sekolah dalam meningkatkan kompetensi guru akidah akhlak dalam menyusunan naskah soal (Studi Kasus di MIN 02 Bengkulu Selatan)," An-Nizom, vol. 5, no. 1, pp. 17-26, 2017.

[2] D. C. Rohim, "Strategi Penyusunan Soal Berbasis HOTs pada Pembelajaran Matematika SD,” J. Ris. dan Konseptual, vol. 4, no. 4, pp. 436-446, 2019, [Online]. Available: http://www.jurnal.unublitar.ac.id/ index.php/briliant.

[3] F. A. Adesoji, "Bloom Taxonomy Of Educational Objectives And The Modification Of Cognitive Levels," Adv. Soc. Sci. Res. J., vol. 5, no. 5, pp. 292-297, 2018, doi: 10.14738/assrj.55.4233.

[4] A. R. Setiawan, "Penyusunan Program Pembelajaran Biologi Berorientasi Literasi Saintifik," Semin. Nas. Sains dan Entrep., vol. VI, no. 23, pp. 1-8, 2019, doi: 10.31226/osf.io/etg5n.

[5] N. R. Mujib, A. J. . Toenlioe, and H. Praherdhiono, "analisis butir soal ujian nasional ipa sd/mi tahun 2015 sampai dengan 2017 berdasarkan taksonomi bloom," Jktp, vol. 1, no. 2, pp. 149-158, 2018.

[6] I. Listiowarni and E. R. Setyaningsih, "Feature Selection Chi-Square dan K-NN pada Pengkategorian Soal Ujian Berdasarkan Cognitive Domain Taksonomi Bloom," J. Komput. Terap., vol. 4, no. 1, pp. 21-30, 2018.

[7] A. Wijaya, A. Eresti, Despa, and A. Walid, "analisis butir soal persiapan ujian nasional ipa smp/mts tahun 2018 sampai dengan 2019 berdasarkan taksonomi bloom," LENSA (Lentera Sains) J. Pendidik. IPA, vol. 9, no. 2, pp. 57-63, 2019.

[8] D. A. Abduljabbar and N. Omar, "Exam questions classification based on Bloom's taxonomy cognitive level using classifiers combination," J. Theor. Appl. Inf. Technol., vol. 78, no. 3, pp. 447-455, 2015.

[9] S. F. Kusuma, D. Siahaan, and U. L. Yuhana, "Automatic Indonesia's questions classification based on bloom's taxonomy using Natural Language Processing a preliminary study," 2015 Int. Conf. Inf. Technol. Syst. Innov. ICITSI 2015 - Proc., pp. 05, 2016, doi: 10.1109/ICITSI.2015.7437696. 
[10] T. Setiyorini and R. T. Asmono, "Penerapan Gini Index Dan K-Nearest Neighbor Untuk Klasifikasi Tingkat Kognitif Soal Pada Taksonomi Bloom," J. Pilar Nusa Mandiri, vol. 13, no. 2, pp. 209-216, 2017.

[11] C. Tristianto, "penggunaan metode waterfall untuk pengembangan sistem monitoring dan evaluasi pembangunan pedesaan," J. Teknol. Inf. ESIT, vol. XII, no. 01, pp. 41-56, 2018, doi: 10.5749/j.cttttv6b.5.

[12] A. Suryadi, "Perancangan Aplikasi Game Edukasi Menggunakan Model Waterfall," $J$. Petik, vol. 3, no. 1, p. 8, 2018, doi: 10.31980/jpetik.v3i1.352.

[13] R. Utari, "TAKSONOMI BLOOM Apa dan Bagaimana Menggunakannya?," Freshw. Biol., vol. 6, no. 4, pp. 301-315, 2017, doi: 10.1111/j.1365-2427.1976.tb01616.x.

[14] K. Jayakodi, M. Bandara, and I. Perera, "An Automatic Classifier for Exam Questions in Engineeering: A Process for Bloom's Taxonomy," IEEE Int. Conf. Teaching, Assessment, Learn. Eng., no. December, pp. 195-202, 2015.

[15] B. Said and F. Prasetyo E.P., "Layanan e-Surat Berbasis Mobile Application di Desa Waru Barat Pamekasan," InfoTekJar (Jurnal Nas. Inform. dan Teknol. Jaringan), vol. 4, no. 1, pp. 111-115, 2019, doi: 10.30743/infotekjar.v4i1.1637.

[16] Z. Sharfina and H. B. Santoso, "An Indonesian adaptation of the System Usability Scale (SUS)," 2016 Int. Conf. Adv. Comput. Sci. Inf. Syst. ICACSIS 2016, pp. 145-148, 2017, doi: 10.1109/ICACSIS.2016.7872776.

[17] U. Ependi, F. Panjaitan, and H. Hutrianto, "System Usability Scale Antarmuka Palembang Guide Sebagai Media Pendukung Asian Games XVIII," J. Inf. Syst. Eng. Bus. Intell., vol. 3, no. 2, p. 80, 2017, doi: 10.20473/jisebi.3.2.80-86.

[18] D. W. Ramadhan, "Pengujian usability website time excelindo menggunakan system usability scale (sus) (studi kasus: website time excelindo)," JIPI (Jurnal Ilm. Penelit. dan Pembelajaran Inform., vol. 4, no. 2, p. 139, 2019, doi: 10.29100/jipi.v4i2.977.

[19] Y. D. Setiyaningrum, A. F. Herdajanti, C. Supriyanto, and Muljono, "Classification of twitter contents using chi-square and K-nearest neighbour algorithm," Proc. - 2019 Int. Semin. Appl. Technol. Inf. Commun. Ind. 4.0 Retrosp. Prospect. Challenges, iSemantic 2019, pp. 78-81, 2019, doi: 10.1109/ISEMANTIC.2019.8884290.

[20] C. F. Suharno, M. A. Fauzi, and R. S. Perdana, "Klasifikasi Teks Bahasa Indonesia Pada Dokumen Pengaduan Sambat Online Menggunakan Metode K-Nearest Neighbors Dan Chi-square," Syst. Inf. Syst. Informatics J., vol. 3, no. 1, pp. 25-32, 2017, doi: 10.29080/systemic.v3i1.191.

[21] O. S. Bachri, Kusnadi, M. Hatta, and O. D. Nurhayati, "Feature selection based on CHI square in artificial neural network to predict the accuracy of student study period," Int. J. Civ. Eng. Technol., vol. 8, no. 8, pp. 731-739, 2017.

[22] Y. Yang and J. Pedersen, "A Comparative Study on Feature Selection in Text Categorization," 1997.

[23] M. Danil, S. Efendi, and R. Widia Sembiring, "The Analysis of Attribution Reduction of K-Nearest Neighbor (KNN) Algorithm by Using Chi-Square," J. Phys. Conf. Ser., vol. 1424, no. 1, 2019, doi: 10.1088/1742-6596/1424/1/012004.

[24] F. F. Laksana and S. Suyoto, "Pengukuran Kualitas Ux Website Menggunakan Sus," Comput. Eng. Sci. Syst. J., vol. 4, no. 2, p. 138, 2019, doi: 10.24114/cess.v4i2.12928.

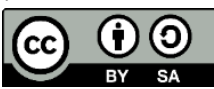

Digital Zone: Jurnal Teknologi Informasi dan Komunikasi is licensed under a Creative Commons Attribution International (CC BY-SA 4.0) 